\title{
Rubinstein-Taybi syndrome: clinical features, genetic basis, diagnosis, and management
}

\author{
Donatella Milani ${ }^{1}$, Francesca Maria Paola Manzoni ${ }^{1}$, Lidia Pezzani ${ }^{1}$, Paola Ajmone ${ }^{2}$, Cristina Gervasini ${ }^{3}$, \\ Francesca Menni ${ }^{1}$ and Susanna Esposito ${ }^{1 *}$
}

\begin{abstract}
Background: Rubinstein-Taybi syndrome (RSTS) is an extremely rare autosomal dominant genetic disease, with an estimated prevalence of one case per 125,000 live births. RSTS is characterized by typical facial features, microcephaly, broad thumbs and first toes, intellectual disability, and postnatal growth retardation. However, no standard diagnostic criteria are available for RSTS. In this review, we summarized the clinical features and genetic basis of RSTS and highlighted areas for future studies on an appropriate diagnostic protocol and follow-up care for RSTS.

Discussion: RSTS is primarily characterized by delayed growth in height and weight, microcephaly, dysmorphic facial features, and broad thumbs and big toe. Over 90\% RSTS individuals with disabilities survive to adulthood, but healthcare for these patients is particularly complex, time-consuming, and costly. In addition, no standard diagnostic criteria and follow-up care guidelines are available for RSTS. It has been shown that mutations in the genes encoding the cyclic-AMP-regulated enhancer binding protein (CREBBP) and the E1A-binding protein p300 (EP300) contributed to the development of RSTS. Therefore, genetic tests are useful for the diagnosis of RSTS, although most RSTS cases are currently diagnosed based on clinical features.

Summary: The clinical features of RSTS have been extensively studied, which significantly contributes to the diagnosis of this extremely rare syndrome. However, the pathogenesis and genotype-phenotype associations of RSTS are largely unknown. Therefore, multicenter studies and international cooperation are highlighted for better understanding of this disease, establishing standard diagnostic criteria, and providing professional management and follow-up care of RSTS.
\end{abstract}

Keywords: CREBBP, Intellectual disability, Plurimalformative syndrome, Rubinstein syndrome, Rubinstein-Taybi syndrome

\section{Background}

Plurimalformative syndromes, which are named according to their low prevalence and incidence in the population, consist of a large group of rare diseases. Rubinstein-Taybi syndrome (RSTS, OMIM \#180849, \#613684) is an extremely rare disease and was first described in 1963 [1]. The incidence of RSTS is 1 in 100,000 to 125,000 live births. Currently, no precise diagnostic criteria are available, although RSTS is primarily characterized by poor postnatal height-weight growth, intellectual disability, microcephaly, dysmorphic facial features, broad thumbs, and big first toes. While a number of major malformations

\footnotetext{
* Correspondence: susanna.esposito@unimi.it

'Pediatric Highly Intensive Care Unit, Department of Pathophysiology and Transplantation, Università degli Studi di Milano, Fondazione IRCCS Ca' Granda Ospedale Maggiore Policlinico, Via Commenda 9, 20122 Milano, Italy Full list of author information is available at the end of the article
}

and clinical complications are associated with RSTS, these signs and symptoms cannot be considered pathognomonic to RSTS. Until the 90s, diagnosis has remained exclusively clinical and radiological ( $x$-ray of hands and feet). The genetic bases were first identified in 1991, demonstrating a de novo reciprocal translocation with breakpoints in chromosomal region 16p13.3 in some patients [2-4]. Subsequently, affected subjects were analyzed using Fluorescent In Situ Hybridization (FISH). In six cases, the hybridization signal was present on only one allele on 16p13.3, confirming that the absence of this region lead to RSTS $[5,6]$. Additional research has led to the discovery of mutations in the gene encoding cyclic-AMP-regulated enhancer binding protein (CREBBP) in 16p13.3 in RSTS patients [7]. Mutations of $C R E B B P$ gene were reported in

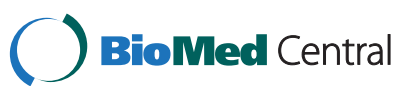

(C) 2015 Milani et al.; licensee BioMed Central. This is an Open Access article distributed under the terms of the Creative Commons Attribution License (http://creativecommons.org/licenses/by/4.0), which permits unrestricted use, distribution, and reproduction in any medium, provided the original work is properly credited. The Creative Commons Public Domain Dedication waiver (http://creativecommons.org/publicdomain/zero/1.0/) applies to the data made available in this article unless otherwise stated 
approximately half of RSTS patients [8,9]. CREBBP gene and its homolog, E1A binding protein p300 (EP300) on chromosome 22, are involved in a number of basic cellular activities, such as DNA repair, growth, differentiation, apoptosis of cells, and tumor suppression by serving as transcriptional co-activators in different signaling pathways [10]. As CREBBP and EP300 interact closely, studies have been conducted to investigate whether mutations in EP300 were associated with RSTS. The results of EP300 sequencing in a group of six subjects revealed three mutations [11]. Subsequently, the incidence of EP300 mutations was estimated as about 5-8\% [12-16]. Generally, $55-70 \%$ clinically diagnosed RSTS cases were confirmed through genetic testing [17]. In this review, we discussed the clinical features and genetic studies of RSTS and we try to outline future directions for an appropriate clinical diagnosis and follow-up of this condition.

\section{Discussion}

\section{Typical features}

RSTS is characterized by slow development of height and weight, microcephaly, dysmorphic facial features, broad thumbs, and big toes [18]. The prenatal development is normal, with average or near-normal growth parameters at birth. The growth charts typically approach the lower limits of normality in the first postnatal period, primarily reflecting hypo-feeding exacerbated by gastroesophageal reflux. Subsequently, the tendency of overweight or obesity (earlier in males than females) can be observed during adolescence. Specific and recently reviewed growth charts are essential for appropriate assessment of the growth of affected individuals [18]. Facial features are primarily characterized by low frontal hairline, arched/thick eyebrows, downslanting of palpebral fissures, a protruding beaked nose with columella below alae nasi, dysplastic and low-set ears, an arched palate, mild micrognathia, dental anomalies (altered conformation, malocclusion, and overcrowding of teeth), and atypical smile ("grimacing") with nearly completely closed eyes (Figure 1). The feet and hands typically present an enlarged first finger and clinodactyly of the fifth finger (Figure 2), whereas polydactyly with bifid thumbs and first toes is rarely observed. Other skeletal anomalies include abducted thumbs, vertebral anomalies, ligamentous laxity, severe and prolonged aseptic inflammation of the femur head, anomalies similar with Perthes disease (3\%), and occasionally slipped capital femoral epiphysis $[19,20]$. Particularly, high risk of cervical vertebral abnormalities (instability of $\mathrm{C} 1-\mathrm{C} 2$, os odontoideum, hypoplasia of the dens, fusion of the cervical vertebrae) has been reported [21-23], with possible stenosis at the craniovertebral junction, which may cause cervical myelopathy. Complex neuroradiological issues including corpus callosum dysgenesis (17\%) [24,25], Chiari type I malformation with or without syringomyelia [25-28], Dandy Walker malformation and hydrocephalus [29,30], and tethered cord [27,31] have been reported and are still under investigation. Cerebrovascular abnormalities such as spontaneous dissection of the supraaortic arteries [32] and cerebral infarction due to dissecting aneurysm of the anterior cerebral artery have also been reported [33]. However, any organ can be affected in RSTS patients. Possible malformations, medical problems, and complications include (Table 1):

- conductive and/or sensorineural deafness, recurrent middle ear infections, recurrent respiratory infections, immune deficiencies [34-36];

- nonspecific abnormalities of electroencephalography (EEG) (57-66\%) and seizures (25\%) [37,38];

- cataract, unilateral or bilateral iris/retinal/optic nerve coloboma (9-11\%), glaucoma, lacrimal duct obstructions (38-47\%), refractive errors (41-56\%), and strabismus (60-71\%) [39-41]. In addition, Jacobs et al. described for the first time peripheral avascularity with fluorescein angiography in 2012 [42];

- dental problems: talon cusps (73\%), enamel hypoplasia, and abnormal tooth number $[43,44]$;

- congenital heart diseases: atrial septal defect, ventricular septal defect, patent ductus arteriosus, coarctation of the aorta, pulmonic stenosis, bicuspid aortic valve, pseudotruncus, aortic stenosis, dextrocardia, vascular rings, and conduction disorders (24-38\%) [45]. Occasional association of hypoplastic left heart with RSTS has also been reported [46];

- renal malformations (52\%) and cryptorchidism (78-100\%) [47];

- endocrine disorders: congenital hypothyroidism $[48,49]$, thyroid hypoplasia, GH deficiency, and pituitary hypoplasia [28];

- gastrointestinal disorders: gastroesophageal reflux, constipation (40-74\%), and megacolon/Hirschsprung disease [47,50];

- obstructive sleep apnea, anesthetic and intubation complications [51,52];

- skin problems including pilomatrixomas, ingrown toenails, paronychia, and the tendency to form keloids (24\%) [53,54];

- cancers, particularly of neural and developmental origins (neuroblastoma, medulloblastoma, oligodendroglioma, meningeoma, pheochromocytoma, rhabdomyosarcoma, leiomyosarcoma, seminoma, odontoma, choristoma, and pilomatrixomas [55-63]. Leukemia and lymphoma have also been reported [55];

- hirsutism.

The neonatal period of individuals with RSTS is typically characterized by hypotonia and delayed psycho- 


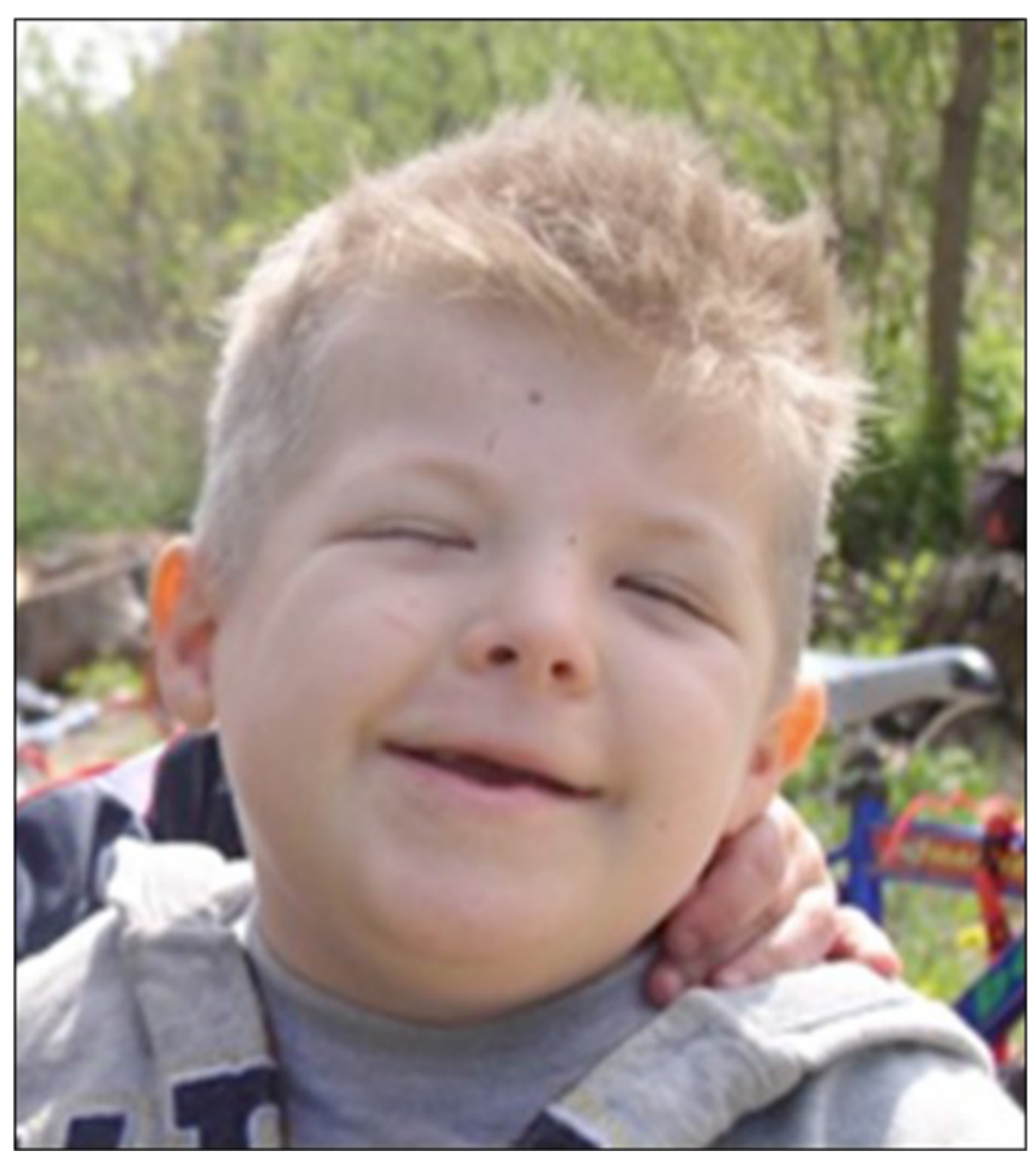

Figure 1 Typical facies of a RSTS patient, including arched eyebrows, slanted palpebral fissures, protruding beaked nose with columella below alae nasi, arched palate, mild micrognathia, labial commissures facing upward, teeth anomalies, and an atypical smile ("grimacing") with nearly completely closed eyes.

motor development, with variable degrees of intellectual disability. For example, the intelligence quotient (IQ) score of RSTS patients in neonatal period usually ranges from 25 to 79 (average: 36-51) [64,65]. In 2009, Galèra et al. described three RSTS cardinal features, short attention span, motor stereotypies, and poor coordination [66]. Both RSTS patients with classical RSTS and mild intellectual disability $[64,67]$ and RSTS patients with atypical RSTS and mild intellectual disability have been reported [68]. Therefore, in the mildest cases, an early diagnosis is particularly difficult, and the main stages of development must be strictly followed to rapidly initiate specific and individualized stimulation. In addition, although RSTS patients usually have friendly and sociable characteristics, behavioral disorders, mood swings, and obsessivecompulsive disorders can still be observed, particularly in adulthood $[64,65,69]$.

\section{Transition and healthcare in adulthood}

Over 90\% individuals with RSTS survive to adulthood [70], and healthcare for these patients is particularly complex, time-consuming, and often not standardized in specific guidelines. The medical problems of most genetic syndromes often change with ages and there is limited knowledge about the management of adults with genetic syndromes [71]. Adult individuals with RSTS have been documented $[13,59,68,72]$, but only a few review studies on adults with RSTS are available $[40,57,69,73]$. In these review studies, adult RSTS patients had relevant medical problems and most of them had overweight or obesity. A number of behavioural phenotypes such as anxiety, mood instability, and aggressive behaviour can appear during adolescence. Caregivers reported decreased abilities over time in 32\% RSTS subjects and some worsening behaviors in 37\% RSTS patients, 


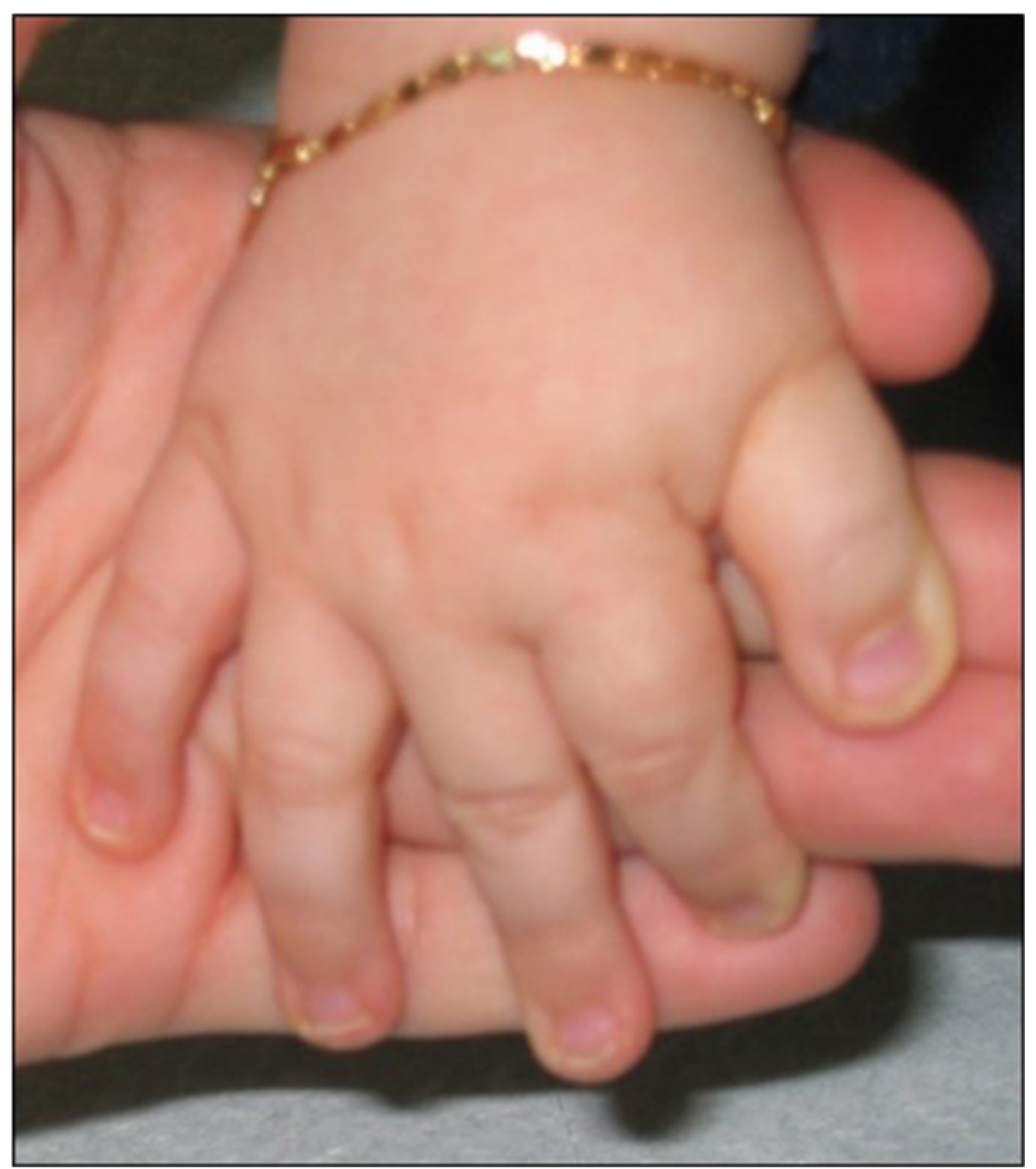

Figure 2 Typical hands of a RSTS patient, including enlarged first finger and clinodactyly of the fifth finger.

which is consistent with the report by Hennekam et al. in 1992 [64]. Therefore, follow-up care is important to identify and treat the psychiatric problems that emerge with age [65]. Finally, the prevalence of RSTS may be higher than original estimation due to late diagnosis particularly in the milder cases [74].

\section{Diagnostic approaches}

Individuals with suspected RSTS should be evaluated by pediatric geneticists knowledgeable in dysmorphology. A number of molecular techniques are widely used in genetic analyses of RSTS. Among the assays, karyotype analysis may show rare cytogenetically visible abnormalities (translocations, inversions, or deletions); although the result is usually normal, this assessment should in any case be performed to identify possible rearrangements. FISH can identify microdeletions, with a detection rate of $5-10 \%[38,75]$. Deletion/duplication analysis testing identifies exonic or whole-gene deletions/duplications not detectable by sequence analysis of the coding and flanking intronic regions of genomic DNA. Various methods may be used (quantitative PCR, long-range PCR, multiplex ligationdependent probe amplification (MLPA), and chromosomal microarray). Stef et al. detected deletions in 17 (20.5\%) of 83 patients using array-CGH and quantitative multiplex fluorescent-PCR [76]. Molecular analysis can also identify mutations in CREBBP and EP300 genes. Pathogenic variants of the $C R E B B P$ gene were identified in $50-70 \%$ of RSTS individuals $[8,9,38,77]$, while mutations in the EP300 gene have been reported in about 5-8\% RSTS patients by Roelfsema et al. [2005], Bartholdi et al. [2007], Negri et al. [2014] [11,12,16].

\section{Genotype-phenotype correlations}

Little is known about genotype-phenotype correlations of RSTS. A severe phenotype has been reported in RSTS 
Table 1 The incidence of a number of typical features of RSTS

\begin{tabular}{ll}
\hline Feature & Incidence (\%) \\
\hline Typical facial features & 100 \\
Intellectual disability & $\sim 100$ \\
Cryptorchidism & $78-100$ \\
Microcephaly & $35-94$ \\
Broad thumbs/halluces & 96 \\
Speech delay & 90 \\
Recurrent respiratory infections & 75 \\
Delayed bone age & 74 \\
Constipation & $40-74$ \\
Talon cusps & 73 \\
Gastroesophageal reflux & 68 \\
EEG abnormalities & $57-66$ \\
Renal anomalies & 52 \\
Refractive defects, glaucoma, retinopathy & $>50$ \\
Congenital heart defects & $24-38$ \\
Seizures & 25 \\
Keloids & 24 \\
Deafness & 24 \\
Growth retardation & 21 \\
Malignant tumors & $3-10$ \\
Spinal cord tethering & $<5$ \\
\hline
\end{tabular}

patients with large deletions [78], but other studies [76,79] do not support this genotype-phenotype association. However, an association between lower IQ and autistic features with large deletions in RSTS patients is possible [38]. Therefore, Calì et al. recommended MLPA that can identify these large deletions for screening RSTS patients with lower IQ and autistic features [80]. Mutations outside the histone acetyltransferase (HAT) domain were associated with a mild phenotype [Spena et al., submitted]. In addition, somatic mosaicism may also be associated with mild RSTS $[9,81,82]$. Less than 20 RSTS patients with EP300 mutations have been identified and characterized till now. EP300 mutations have been associated with preeclampsia in women carrying a pregnancy affected by RSTS; skin involvement and a mild phenotype in skeletal abnormalities and neuropsychiatric issues are described [12-16,83].

\section{Genetic counseling}

Most RSTS cases are sporadic and only a few RSTS cases affecting siblings have been reported to date $[1,82,84-86]$. Vertical transmission is extremely rare [75,86-89]. While the recurrence risk of RSTS is generally low, proper genetic counseling should be provided for prenatal diagnosis of RSTS. Somatic mosacism, for example, was confirmed in the clinically unaffected father of a boy with RSTS [82] and in the mildly affected father of three females with RSTS [89]. In addition, germline mosaicism was hypothesized in two RSTS cases $[17,82]$. Based on these reports, the recurrence risk of RSTS is approximately $0.5-1 \%$.

\section{Management}

While significant advance in the knowledge of clinical manifestations and natural history of RSTS has been made, guidelines for the healthcare and follow-up care of RSTS have not been well updated after the proposal of Wiley et al. in 2003 (Table 2) [37]. Novel genetic and epigenetic therapies may be promising approaches for the treatment of RSTS $[90,91]$, but there is an urgent need to improve and personalize the standard follow up protocol. On the basis of our knowledge and of the critical aspects that we discuss below, we drafted our proposal for follow-up (Table 3).

Management should be adjusted in adolescent age, for the known differences in some issues (ophthalmological features, tendency to obesity and mood disorders in particular).

\section{Unknown and critical issues in RSTS}

Substantial progress has been made in studies of the genetic basis and medical issues of RSTS, which contributes

Table 2 Traditional medical guidelines for RSTS management

\begin{tabular}{|c|c|c|c|c|c|c|c|}
\hline & Diagnosis & $6 M$ & $1 Y$ & $18 M$ & $2 Y$ & $30 \mathrm{M}$ & $>3 Y$ (yearly) \\
\hline Audiologic evaluation & $x$ & $x$ & $x$ & $x$ & $x$ & $x$ & $x$ \\
\hline Ophtalmologic evaluation & $x$ & $x$ & & $x$ & & $x$ & $x$ \\
\hline Orthopedic evaluation & $x$ & $x$ & $x$ & $x$ & $x$ & $x$ & $x$ \\
\hline Cardiologic evaluation* & $x$ & & & & & & \\
\hline Pressure measurement & & & & & & & $x$ \\
\hline Renal US scan* & $x$ & & & & & & \\
\hline Odonthoiatric evaluation & & & $x$ & $x$ & $x$ & $x$ & $x$ \\
\hline Genetic counseling & $x$ & & & & & & \\
\hline
\end{tabular}


Table 3 Our proposal for medical guidelines in patients with RSTS

\begin{tabular}{|c|c|c|c|c|c|c|c|c|}
\hline & Diagnosis & $6 M$ & $1 Y$ & $18 \mathrm{M}$ & $2 Y$ & $30 \mathrm{M}$ & $>3 Y$ (yearly) & Adolescent age \\
\hline Brain and medullary NMR* & $x$ & & & & & & & $x$ \\
\hline Neuropsychiatric evaluation & $x$ & & & & & & & $x$ \\
\hline Audiologic evaluation & $x$ & $x$ & $x$ & $x$ & $x$ & $x$ & $x$ & $x$ \\
\hline Ophtalmologic evaluation & $x$ & $x$ & & $x$ & & $x$ & $x$ & $x$ \\
\hline Orthopedic evaluation & $x$ & $x$ & $x$ & $x$ & $x$ & $x$ & $x$ & $x$ \\
\hline Cardiologic evaluation* & $x$ & & & & & & & $x$ \\
\hline Pressure measurement & & & & & & & $x$ & $x$ \\
\hline Renal US scan* & $x$ & & & & & & & $x$ \\
\hline Odonthoiatric evaluation & & & $x$ & $x$ & $x$ & $x$ & $x$ & $x$ \\
\hline Endocrinological evaluation* & $x$ & & & & & $x$ & & $x$ \\
\hline Dermatologic evaluation* & $x$ & & & & & & & $x$ \\
\hline Genetic counseling & $x$ & & & & & & & $x$ \\
\hline
\end{tabular}

$\mathrm{M}=$ months, $\mathrm{Y}=$ years .

*Follow-up if necessary.

to initial clinical diagnosis and subsequent confirmation through molecular analyses. Given the complexity and rarity of this syndrome, there are still numerous unanswered questions about RSTS. Therefore, further investigations should be focused. on clinical diagnosis and management as well as on genotype-phenotype correlation.

Based on our experience, abnormal growth patterns as seen on standard growth charts should be highlighted in the diagnostic criteria of RSTS. In addition, clinical diagnostic criteria and screening could be further classified according to prenatal, childhood, and adolescent periods. Particularly, the presence of normal growth in utero, associated with other markers such as broad thumbs/ halluces and other malformations, is useful in differential diagnosis of RSTS from other syndromes (i.e., Cornelia de Lange syndrome). Pediatric geneticists should pay more attention to widened distal phalanges: reviewing patients' photos sent to molecular analyses we found in a great majority this sign, not reported in clinical charts. Enlarged first finger is a feature largely known, but also common in other syndromes such as acrocephalopolysyndactyly, whereas distal phalanges conformation seems more specific for RSTS. Moreover, talon cusps that are often overlooked are also highly specific for RSTS. A multicenter prevalence study of brain and spine abnormalities is needed, in view of the several reports and of the both diagnostic and prognostic meaning of these features; a screening brain/medullary MRI could be useful in addition to basic diagnostic work-up. Furthermore, regarding endocrinological features, more informations were recently added, regarding in particular thyroid shape and function, and we are personally aware of other two cases with mild hypothyiroidism and small thyroid. In addition to intellectual disability, some behavioral changes are known for RSTS patients, but no significant evidence supports the diagnostic values of these neuropsychiatric features in RSTS diagnosis. Therefore, no neuropsychiatric features are strong enough to be included in the diagnostic criteria of RSTS although some features may be more suggestive of EP300 mutations. In these cases, ID is mild or absent, and behavioral disturbance (i.e. anxiety) predominates. Other features suggestive of EP300 mutations include pre-eclampsia [92] and less significant abnormalities in the firs digit, giving the cue for drawing up differential criteria for EP300, and for a more precise and individualized laboratory flow-chart. To the best of our knowledge, this is the only possible change in the order of molecular investigations, as other genotypephenotype correlations are only tentative. Numerous nonspecific complications may occur during the follow-up care of RSTS; therefore, it is difficult to establish a general and efficient follow-up protocol. In addition, no robust genotype-phenotype correlations have been identified. In general, orthopaedic follow-up, dietary monitoring in adolescence and neuropsychiatric periods, and ophthalmologic evaluations in adults should be focused. A less strict follow-up protocol may be only appropriate for RSTS patients with EP300 mutations [16], with focus on skin problems (pilomatrixomas and nevi) that are likely more frequent than in patients with CREBBP mutations. Regarding genetic counselling, salivary brush and genetic tests are important for the evaluation of recurrence risk in parents with germinal and somatic mosaicism.

A discussion about critical aspects of progresses in understanding of RSTS etiopathogenesis is out of the scope of this review, but different mouse models have been made with interesting results [90]. 


\section{Conclusions}

RSTS is an extremely rare condition for which some clinical aspects have been clearly identified, but a lot of studies are ongoing and needed. Multicenter studies are needed to expand our knowledge on the clinical phenotype, identify specific genotype-phenotype correlations, evaluate the presence of somatic mosaicisms to better define mild phenotypes, and identify new candidate genes. The ultimate goal of these studies is to extend our current knowledge concerning this syndrome and to define new international guidelines for diagnosis, care and treatment of patients with RSTS.

\section{Summary}

RSTS is an extremely rare multiple congenital anomaly/ intellectual disability syndrome, with an estimated prevalence of one case per 125,000 live births. No precise diagnostic criteria have been defined, although the distinctive features include typical facial features, microcephaly, broad thumbs and first toes, intellectual disability and postnatal growth retardation. RSTS is mainly characterized by poor growth in height and weight, microcephaly, dysmorphic facial features, broad thumbs and big toe. Several organs and systems may be affected, but none of other signs or symptoms can be considered pathognomonic. More than $90 \%$ of individuals with disabilities survive into adulthood, and health care for these patients is particularly complex, time-consuming, often not standardized in specific guidelines. The gene most frequently involved is cyclic-AMP-regulated enhancer binding protein $(C R E B B P)$; alterations in the E1A-binding protein p300 (EP300) have also been detected, but many cases have only been clinically diagnosed. Future multicenter studies are necessary to expand our knowledge on the clinical phenotype, identify specific genotype-phenotype correlations, evaluate the presence of somatic mosaicisms to better define mild phenotypes, and identify new candidate genes. The ultimate goal of these studies is to extend our current knowledge concerning this syndrome and to define new international guidelines for diagnosis, care and treatment of patients with RSTS.

\section{Ethical approval}

The follow-up studies of RSTS children performed by the authors have been approved by the Ethics Committee of Fondazione IRCCS Ca' Granda Ospedale Maggiore Policlinico, Milan, Italy.

\section{Consent}

Written informed consent was obtained from the patients' parents for the publication of this report and any accompanying images.

\section{Abbreviations}

RSTS: Rubinstein-Taybi syndrome; CREBBP: Cyclic-AMP-regulated enhancer binding protein; EP300: E1A binding protein p300; FISH: Fluorescent in situ hybridization; HAT: Histone acetyltransferase; IQ: Intelligence quotient; MLPA: Multiplex ligation-dependent probe amplification.

\section{Competing interests}

The authors declare that they have no competing interests.

\section{Authors' contributions}

DM, FMPM, LP, PA, CG and FM drafted the manuscript and followed the RSTS patients at Fondazione IRCCS Ca' Granda Ospedale Maggiore Policlinico, Milan, Italy. SE, the Director of the Unit where the patients were followed, revised the manuscript and made substantial scientific contributions. All authors have read and approved the final version of the manuscript.

\section{Acknowledgments}

The authors thank Italian Association RTS Una vita speciale for the precious awareness work on public opinion.

\section{Funding}

This study was supported by grants from the Italian Ministry of Health (Bando Giovani Ricercatori 2009).

\section{Author details}

${ }^{1}$ Pediatric Highly Intensive Care Unit, Department of Pathophysiology and Transplantation, Università degli Studi di Milano, Fondazione IRCCS Ca' Granda Ospedale Maggiore Policlinico, Via Commenda 9, 20122 Milano, Italy. ${ }^{2} \cup O$ Neuropsichiatria dell'Infanzia e dell'Adolescenza, Fondazione IRCCS Ca' Granda Ospedale Maggiore Policlinico, Milano, Italy. ${ }^{3}$ Department of Health Science, Medical Genetics, Università degli Studi di Milano, Milano, Italy.

Received: 19 October 2014 Accepted: 7 January 2015

Published online: 20 January 2015

\section{References}

1. Rubinstein $\mathrm{JH}$, Taybi H. Broad thumbs and toes and facial abnormalities. A possible mental retardation syndrome. Am J Dis Child. 1963;105:588-608.

2. Imaizumi K, Kuroki Y. Rubinstein-Taybi syndrome with de novo reciprocal translocation t(2;16)(p13.3;p13.3). Am J Med Genet A. 1991;38:636-9.

3. Lacombe D, Saura R, Taine $L$, Battin J. Confirmation of assignment of a locus for Rubinstein- Taybi syndrome gene to 16p13.3. Am J Med Genet A. 1992;44:126-8

4. Tommerup $\mathrm{N}$, van der Hagen $\mathrm{CB}$, Heiberg $\mathrm{A}$. Tentative assignment of locus for Rubinstein-Taybi syndrome to $16 \mathrm{p} 13.3$ by a de novo reciprocal translocation, t(7;16)(q34;p13.3). Am J Med Genet A. 1992;44:237-41.

5. Breuning MH, Dauwerse HG, Fugazza G, Saris JJ, Spruit L, Wijnen $H$, et al. Rubinstein-Taybi syndrome caused by submicroscopic deletions within 16p13.3. Am J Hum Genet. 1993;52:249-54.

6. Hennekam RC, Tilanus M, Hamel BC, Voshart-van Heeren H, Mariman EC, van Beersum SE, et al. Deletion at chromosome 16p13.3 as a cause of Rubinstein-Taybi syndrome: clinical aspects. Am J Hum Genet. 1993;52:255-62.

7. Petrij F, Giles RH, Dauwerse HG, Saris JJ, Hennekam RC, Masuno M, Tommerup N, van Ommen GJ, Goodman RH, Peters DJ. Rubinstein-Taybi syndrome caused by mutations in the transcriptional co-activator CBP. Nature. 1995;376:348-51.

8. Coupry I, Roudaut C, Stef M, Delrue MA, Marche M, Burgelin I, et al. Molecular analysis of the CBP gene in 60 patients with Rubinstein-Taybi syndrome. J Med Genet. 2002;39:415-21.

9. Bentivegna A, Milani D, Gervasini C, Castronovo P, Mottadelli F, Manzini S, et al. Rubinstein-Taybi syndrome: spectrum of CREBBP mutations in Italian patients. BMC Med Genet. 2006;7:77

10. Goodman RH, Smolik S. CBP/p300 in cell growth, transformation, and development. Genes Dev. 2000;14:1553-77.

11. Roelfsema JH, White SJ, Ariyürek Y, Bartholdi D, Niedrist D, Papadia F, et al. Genetic heterogeneity in Rubinstein-Taybi syndrome: mutations in both the CBP and EP300 genes cause disease. Am J Hum Genet. 2005;76:572-80.

12. Bartholdi D, Roelfsema JH, Papadia F, Breuning MH, Niedrist D, Hennekam $\mathrm{RC}$, et al. Genetic heterogeneity in Rubinstein-Taybi syndrome: delineation 
of the phenotype of the first patients carrying mutations in EP300. J Med Genet. 2007:44:327-33.

13. Bartsch O, Labonté J, Albrecht B, Wieczorek D, Lechno S, Zechner U, et al. Two patients with EP300 mutations and facial dysmorphism different from the classic Rubinstein-Taybi syndrome. Am J Med Genet A. 2010;152A:181-4.

14. Tsai AC, Dossett CJ, Walton CS, Cramer AE, Eng PA, Nowakowska BA, et al. Exon deletions of the EP300 and CREBBP genes in two children with RubinsteinTaybi syndrome detected by aCGH. Eur J Hum Genet. 2011;19(1):43-9.

15. Woods SA, Robinson HB, Kohler LJ, Agamanolis D, Sterbenz G, Khalifa M. Exome sequencing identifies a novel EP300 frame shift mutation in a patient with features that overlap Cornelia de Lange syndrome. Am J Med Genet A. 2014;164A:251-8.

16. Negri G, Milani D, Colapietro P, Forzano F, Della Monica M, Rusconi D, et al. Clinical and molecular characterization of Rubinstein-Taybi syndrome patients carrying distinct novel mutations of the EP300 gene. Clin Genet. 2014. doi:10.1111/cge.12348.

17. Tajir M, Fergelot $\mathrm{P}$, Lancelot G, Elalaoui SC, Arveiler B, Lacombe D, et al. Germline mosaicism in Rubinstein-Taybi syndrome. Gene. 2013;518:476-8.

18. Beets L, Rodriguez-Fonseca C, Hennekam RC. Growth charts for individuals with Rubinstein-Taybi syndrome. Am J Med Genet A. 2014;164(9):2300-9.

19. Bonioli E, Bellini C, Sénès FM, Palmieri A, Di Stadio M, Pinelli G. Slipped capital femoral epiphysis associated with Rubinstein-Taybi syndrome. Clin Genet. 1993;44(2):79-81.

20. Shah H, Singh G, Vijayan S, Girisha KM. Second report of slipped capital femoral epiphysis in Rubinstein-Taybi syndrome. Clinical Dysmorphology. 2011:20:55-7.

21. Robson MJ, Brown LM, Sharrard WJ. Cervical spondylolisthesis and other skeletal abnormalities in Rubinstein-Taybi syndrome. J Bone Joint Surg Br. 1980;62:297-9.

22. Yamamoto T, Kurosawa K, Masuno M, Okuzumi S, Kondo S, Miyama S, et al. Congenital anomaly of cervical vertebrae is a major complication of Rubinstein-Taybi syndrome. Am J Med Genet A. 2005;135:130-3.

23. Marzuillo P, Grandone A, Luongo C, Cantelmi G, Polito C, del Giudice EM, et al. Brain magnetic resonance in the routine management of Rubinstein-Taybi syndrome (RTS) can prevent lifethreatening events and neurological deficits. Am J Med Genet A. 2014;164A:2129-32.

24. Rubinstein JH. Broad thumb-hallux (Rubinstein-Taybi) syndrome 1957-1988. Am J Med Genet Suppl. 1990;6:3-16.

25. Wojcik C, Volz K, Ranola M, Kitch K, Karim T, O'Neil J, et al. Rubinstein-Taybi syndrome associated with Chiari type I malformation caused by a large 16p13.3 microdeletion: A contiguous gene syndrome? Am J Med Genet A. 2010:152A:479-83.

26. Parsley L, Bellus G, Handler M, Tsai AC-H. Identical twin sisters with RubinsteinTaybi syndrome associated with Chiari malformations and syrinx. Am J Med Genet A. 2011;155:2766-770.

27. Giussani C, Selicorni A, Fossati C, Ingelmo P, Canonico F, Landi A, et al The association of neural axis and craniovertebral junction anomalies with scoliosis in Rubinstein-Taybi syndrome. Child Nerv Syst. 2012;28:2163-8

28. Marzuillo Grandone A, Coppola R, Cozzolino D, Festa A, Messa F, Luongo C, et al. Novel CAMP binding protein-BP (CREBBP) mutation in a girl with Rubinstein-Taybi syndrome, GH deficiency, Arnold Chiari malformation and pituitary hypoplasia. BMC Medical Genetics. 2013;14:28.

29. Barson AJ. Proceedings: Rubinstein-Taybi syndrome. Arch Dis Child. 1974;49(6):495.

30. Agarwal R, Aggarwal R, Kabra M, Deorari AK. Dandy-Walker malformation in Rubinstein-Taybi syndrome: a rare association. Clin Dysmorphol. 2002;11(3):223-4.

31. Tanaka T, Ling BC, Rubinstein JH, Crone KR. Rubinstein-Taybi syndrome in children with tethered spinal cord. J Neurosurg. 2006;105(4 Suppl):261-4.

32. Fischer $\mathrm{S}$, Bäzner $\mathrm{H}$, Henkes $\mathrm{H}$. Cervical artery dissection in a young patient with Rubinstein-Taybi syndrome. Clin Neuroradiol. 2013;23:41-4.

33. Ishizaka S, Sou G, Morofuji Y, Hayashi K, Kitagawa N, Tateishi Y, et al. Dissecting aneurysm of the anterior cerebral artery with Rubinstein-Taybi syndrome-a case report. Brain Nerve. 2010;62:1083-8.

34. Peñaranda A, Cerón M. Rubinstein-Taybi syndrome and mixed bilateral hypoacousia case report. Otol Neurotol. 2007;28:501-3.

35. Naimi DR, Munoz J, Rubinstein J, Hostoffer Jr RW. Rubinstein-Taybi syndrome: an immune deficiency as a cause for recurrent infections. Allergy Asthma Proc. 2006;:27:281-4
36. Torres LC, Sugayama SM, Arslanian C, Sales MM, Carneiro-Sampaio M. Evaluation of the immune humoral response of Brazilian patients with Rubinstein-Taybi syndrome. Braz J Med Biol Res. 2010;43:1215-24.

37. Wiley S, Swayne S, Rubinstein JH, Lanphear NE, Stevens CA. Rubinstein-Taybi syndrome medical guidelines. Am J Med Genet A. 2003;119A:101-10.

38. Schorry EK, Keddache M, Lanphear N, Rubinstein JH, Srodulski S, Fletcher D, et al. Genotype-phenotype correlations in Rubinstein-Taybi syndrome. Am J Med Genet A. 2008;146A:2512-9.

39. Marabotti A, Giannecchini G, Cariello A, Cappelli C, Giannecchini I, Bedei A. Stenosis of the lachrymal system in Rubinstein-Taybi syndrome. Ophthalmol. 2002;216:272-6.

40. Van Genderen MM, Kinds GF, Riemslag FCC, Hennekam RCM. Ocular features in Rubinstein-Taybi syndrome: investigation of 24 patients and review of the literature. Br J Ophthalmol. 2000;84:1177-84.

41. Kosaki R, Fujita H, Takada H, Okada M, Torii C, Kosaki K. Monozygotic twins of Rubinstein-Taybi syndrome discordant for glaucoma. Am J Med Genet A. 2011;155:1189-91.

42. Jacobs DJ, Sein J, Berrocal AM, Grajewski AL, Hodapp E. Fluorescein angiography findings in a case of Rubinstein-Taybi syndrome. Clin Ophthalmol. 2012;6:1369-71.

43. Hennekam RC, Stevens CA, Van de Kamp JJ. Etiology and recurrence risk in Rubinstein- Taybi syndrome. Am J Med Genet. 1990;6:56-64.

44. Bloch-Zupan A, Stachtou J, Emmanouil D, Arveiler B, Griffiths D, Lacombe D. Oro- dental features as useful diagnostic tool in Rubinstein-Taybi syndrome. Am J Med Genet A. 2007;143:570-3.

45. Stevens CA, Bhakta MG. Cardiac abnormalities in the Rubinstein-Taybi syndrome. Am J Med Genet A. 1995;59:346-8.

46. Hanauer D, Argilla M, Wallerstein R. Rubinstein-Taybi syndrome and hypoplastic left heart. Am J Med Genet A. 2002;112:109-11.

47. Hennekam RCM. Rubinstein-Taybi syndrome. In: Cassidy SB, Allanson JE, editors. Management of genetic syndromes. 3rd ed. Hoboken, NJ: Wiley-Blackwell; 2010. p. 705-15.

48. Olson DP, Koenig RJ. Thyroid function in Rubinstein-Taybi syndrome. J Clin Endocrinol Metab. 1997;82:3264-6.

49. Kurtoglu S, Akcakus M, Gunes T, Cetin N, Topaloglu N. Congenital hypothyroidism associated with Rubinstein-Taybi syndrome. J Pediatr Endocrinol Metab. 2003;16:457-9.

50. Isidor B, Podevin G, Camby C, Mosnier J-F, Chauty A, Lyet J-M, et al. RubinsteinTaybi syndrome and Hirschsprung disease in a patient harbouring an intragenic deletion of the CREBBP gene. Am J Med Genet A. 2010;152A:1847-8.

51. Zucconi M, Ferini-Strambi L, Erminio C, Pestalozza G, Smirne S. Obstructive sleep apnea in the Rubinstein-Taybi syndrome. Respiration. 1993:60:127-32.

52. Choi HS. Pulmonary hypertension due to obstructive sleep apnea in a child with Rubinstein-Taybi syndrome. Korean J Pediatr. 2012;55:212-14.

53. Bayle P, Bazex J, Lamant L, Lauque D, Durieu C, Albes B. Multiple perforating and non perforating pilomatricomas in a patient with Churg-Strauss syndrome and Rubinstein-Taybi syndrome. J Eur Acad Dermatol Venereol. 2004;18:607-10.

54. van de Kar AL, Houge G, Shaw AC, De Jong D, van Belzen MJ, Peters DJ, Hennekam RC. Keloids in Rubinstein-Taybi Syndrome: a clinical study. Br J Dermatol. 2014 doi:10.1111/bjd.13124.

55. Siraganian PA, Rubinstein JH, Miller RW. Keloids and neoplasms in the Rubinstein-Taybi syndrome. Med Pediatr Oncol. 1989;17:485-91.

56. de Kort E, Conneman N, Diderich K. A case of Rubinstein-Taybi syndrome and congenital neuroblastoma. Am J Med Genet A. 2014;164A:1332-3.

57. Miller RW, Rubinstein JH. Tumors in Rubinstein-Taybi syndrome. Am J Med Genet. 1995:56:112-5.

58. Ihara K, Kuromaru R, Takemoto M, Hara T. Rubinstein-Taybi syndrome: a girl with a history of neuroblastoma and premature thelarche. Am J Med Genet A. 1999;83:365-6.

59. Roelfsema JH, Peters DJ. Rubinstein-Taybi syndrome: clinical and molecular overview. Expert Rev Mol Med. 2007;9:1-16.

60. Bourdeaut F, Miquel C, Richer W, Grill J, Zerah M, Grison C, et al. Rubinstein-Taybi syndrome predisposing to non-WNT, non-SHH, group 3 medulloblastoma. Pediatr Blood Cancer. 2014;61:383-6.

61. Evans G, Burnell L, Campbell R, Gattamaneni HR, Birch J. Congenital anomalies and genetic syndromes in 173 cases of medulloblastoma. Med Pediatr Oncol. 1993;21:433-4.

62. Skousen GJ, Wardinsky T, Chenaille P. Medulloblastoma in patient with Rubinstein-Taybi syndrome. Am J Med Genet A. 1996;66:367. 
63. Taylor MD, Mainprize TG, Rutka JT, Becker L, Bayani J, Drake JM. Medulloblastoma in a child with Rubenstein-Taybi syndrome: Case report and review of the literature. Pediatr Neurosurg. 2001;35:235-8.

64. Hennekam RC, Baselier AC, Beyaert E, Bos A, Blok JB, Jansma HB, et al. Psychological and speech studies in Rubinstein-Taybi syndrome. Am J Ment Retard. 1992;96:645-60.

65. Yagihashi T, Kosaki K, Okamoto N, Mizuno S, Kurosawa K, Takahashi T, et al. Age-dependent change in behavioral feature in Rubinstein-Taybi syndrome. Congenit Anom. 2012;52:82-6.

66. Galéra C, Taupiac E, Fraisse S, Naudion S, Toussaint E, Rooryck-Thambo C, et al. Socio-behavioral characteristics of children with Rubinstein-Taybi syndrome. J Autism Dev Disord. 2009;39:1252-60.

67. Bartsch O, Locher K, Meinecke P, Kress W, Seemanová E, Wagner A, et al. Molecular studies in 10 cases of Rubinstein-Taybi syndrome, including a mild variant showing a missense mutation in codon 1175 of CREBBP. J Med Genet. 2002;39:496-501.

68. Wieczorek D, Bartsch O, Lechno S, Kohlhase J, Peters DJ, Dauwerse H, et al. Two adults with Rubinstein-Taybi syndrome with mild mental retardation, glaucoma, normal growth and skull circumference, and camptodactyly of third fingers. Am J Med Genet A. 2009;149A:2849-854.

69. Stevens CA, Pouncey J, Knowles D. Adults with Rubinstein-Taybi syndrome. Am J Med Genet A. 2011;155:1680-4.

70. Blum RW. Transition to adult health care: Setting the stage. J Adolesc Health. 1995;17:3-5.

71. Schrander-Stumpel CTRM, Williams MS. Adult dysmorphology. Seminars in medical genetics. Am J Med Genet C. 2007;145:321.

72. Nakai K, Yoneda K, Moriue T, Kubota Y. Striate palmoplantar keratoderma in a patient with Rubinstein-Taybi syndrome. J Eur Acad Dermatol Venereol. 2009;23:333-5

73. Levitas AS, Reid CS. Rubinstein-Taybi syndrome and psychiatric disorders. J Intellect Disabil Res. 1998;42:284-92.

74. Li C, Szybowska M. A novel mutation C.4003 G > C in the CREBBP gene in an adult female with Rubinstein-Taybi syndrome presenting with subtle dysmorphic features. Am J Med Genet A. 2010;152A:2939-41.

75. Petrij F, Dauwerse HG, Blough Rl, Giles RH, van der Smagt JJ, Wallerstein R, et al. Diagnostic analysis of the Rubinstein-Taybi syndrome: five cosmids should be used for microdeletion detection and low number of protein truncating mutations. J Med Genet. 2000;37:168-76.

76. Stef M, Simon D, Mardirossian B, Delrue MA, Burgelin I, Hubert C, et al. Spectrum of CREBBP gene dosage anomalies in Rubinstein-Taybi syndrome patients. Eur J Hum Genet. 2007;15:843-7.

77. Bartsch O, Schmidt S, Richter M, Morlot S, Seemanová E, Wiebe G, et al. DNA sequencing of CREBBP demonstrates mutations in 56\% of patients with Rubinstein-Taybi syndrome (RSTS) and in another patient with incomplete RSTS. Hum Genet. 2005;117:485-93.

78. Bartsch O, Rasi S, Delicado A, Dyack S, Neumann LM, Seemanová E, et al. Evidence for a new contiguous gene syndrome, the chromosome 16p13.3 deletion syndrome alias severe Rubinstein-Taybi syndrome. Hum Genet. 2006:120:179-86.

79. Lai AHM, Brett MS, Chin WH, Lim ECP, Ng JSH, Tan EC. A submicroscopic deletion involving part of the CREBBP gene detected by array-CGH in a patient with Rubinstein-Taybi syndrome. Gene. 2012;499:182-5.

80. Calì F, Failla P, Chiavetta V, Ragalmuto A, Ruggeri G, Schinocca P, et al. Multiplex ligation-dependent probe amplification detection of an unknown large deletion of the CREB-binding protein gene in a patient with Rubinstein-Taybi syndrome. Genetics and Molecular Research. 2013;12(3):2809-15

81. Gervasini C, Castronovo P, Bentivegna A, Mottadelli F, Faravelli F, Giovannucci-Uzielli ML, et al. High frequency of mosaic CREBBP deletions in Rubinstein-Taybi syndrome patients and mapping of somatic and germ-line breakpoints. Genomics. 2007;90:567-73.

82. Chiang PW, Lee NC, Chien N, Hwu WL, Spector E, Tsai AC. Somatic and germ-line mosaicism in Rubinstein-Taybi syndrome. Am J Med Genet A. 2009:149A:1463-67.

83. Foley P, Bunyan D, Stratton J, Dillon M, Lynch SA. Further case of Rubinstein-Taybi syndrome due to a deletion in EP300. Am J Med Genet A. 2009;149A:997-1000

84. Padfield CJ, Partington MW, Simpson NE. The Rubinstein-Taybi syndrome. Arch Dis Child. 1968;43(227):94-101

85. Verma IC. Rubinstein Taybi syndrome. Case report. Indian Pediatr. 1970;7:672-4.
86. Cotsirilos P, Taylor JC, Matalon R. Dominant inheritance of a syndrome similar to Rubinstein-Taybi. Am J Med Genet A. 1987;26:85-93.

87. Hennekam RC, Lommen EJ, Strengers JL, Van Spijker HG, Jansen-Kokx TM. Rubinstein-Taybi syndrome in a mother and son. Eur J Pediatr. 1989;14:439-41.

88. Marion RW, Garcia DM, Karasik JB. Apparent dominant transmission of the Rubinstein-Taybi syndrome. Am J Med Genet A. 1993;46:284-7.

89. Bartsch O, Kress W, Kempf O, Lechno S, Haaf T, Zechner U. Inheritance and variable expression in Rubinstein-Taybi syndrome. Am J Med Genet A. 2010;152A:2254-61.

90. Shim JH, Greenblatt MB, Singh A, Brady N, Hu D, Drapp R, et al. Administration of BMP2/7 in utero partially reverses Rubinstein-Taybi syndrome-like skeletal defects induced by Pdk1 or Cbp mutations in mice. Journal of Clin Invest. 2012:122:91-106.

91. Park E, Kim Y, Ryu H, Kowall NW, Lee J, Ryu H. Epigenetic Mechanisms of Rubinstein-Taybi Syndrome. Neuromol Med. 2014;16:16-24.

92. Milani D, Pezzani L, Negri G, Gervasini C, Esposito S. The potential impact of fetal genotype on maternal blood pressure during pregnancy: the example of EP300. J Hypertens. in press.

\section{Submit your next manuscript to BioMed Central and take full advantage of:}

- Convenient online submission

- Thorough peer review

- No space constraints or color figure charges

- Immediate publication on acceptance

- Inclusion in PubMed, CAS, Scopus and Google Scholar

- Research which is freely available for redistribution 